\title{
Tropospheric ozone variability during the East Asian summer monsoon as observed by satellite (IASI), aircraft (MOZAIC) and ground stations
}

\author{
Sarah Safieddine ${ }^{1, \mathrm{a}}$, Anne Boynard ${ }^{1}$, Nan $\mathrm{Hao}^{2}$, Fuxiang Huang ${ }^{3}$, Lili Wang ${ }^{4}$, Dongsheng Ji ${ }^{4}$, Brice Barret ${ }^{5}$, \\ Sachin D. Ghude ${ }^{6}$, Pierre-François Coheur ${ }^{7}$, Daniel Hurtmans ${ }^{7}$, and Cathy Clerbaux ${ }^{1,7}$ \\ ${ }^{1}$ Sorbonne Universités, UPMC Univ. Paris 06, Université Versailles St-Quentin, CNRS/INSU, LATMOS-IPSL, Paris, France \\ ${ }^{2}$ German Aerospace Center (DLR), Remote Sensing Technology Institute (IMF), Oberpfaffenhofen, Germany \\ ${ }^{3}$ National Satellite Meteorological Center, China Meteorological Administration, Beijing, China \\ ${ }^{4}$ LAPC, Institute of Atmospheric Physics, Chinese Academy of Sciences, Beijing, China \\ ${ }^{5}$ Laboratoire d'Aérologie, Observatoire Midi-Pyrénées, Université Paul Sabatier, CNRS, Toulouse, France \\ ${ }^{6}$ Indian Institute of Tropical Meteorology, Pashan Rd., Pune-411 008, India \\ ${ }^{7}$ Spectroscopie de l'Atmosphère, Chimie Quantique et Photophysique, Université Libre de Bruxelles (U.L.B.), \\ Brussels, Belgium \\ ${ }^{a}$ now at: Department of Civil and Environmental Engineering, Massachusetts Institute of Technology, Cambridge, MA, USA
}

Correspondence to: Sarah Safieddine (sarahsaf@mit.edu)

Received: 19 August 2015 - Published in Atmos. Chem. Phys. Discuss.: 13 November 2015

Revised: 24 June 2016 - Accepted: 2 August 2016 - Published: 22 August 2016

\begin{abstract}
Satellite measurements from the thermal Infrared Atmospheric Sounding Interferometer (IASI), aircraft data from the MOZAIC/IAGOS project, as well as observations from ground-based stations, are used to assess the tropospheric ozone $\left(\mathrm{O}_{3}\right)$ variability during the East Asian Summer Monsoon (EASM). Six years 2008-2013 of IASI data analysis reveals the ability of the instrument to detect the onset and the progression of the monsoon seen by a decrease in the tropospheric $0-6 \mathrm{~km} \mathrm{O}_{3}$ column due to the EASM, and to reproduce this decrease from one year to the other. The year-to-year variability is found to be mainly dependent on meteorology. Focusing on the period of May-August 2011, taken as an example year, IASI data show clear inverse relationship between tropospheric $0-6 \mathrm{~km} \mathrm{O}_{3}$ on one hand and meteorological parameters such as cloud cover, relative humidity and wind speed, on the other hand. Aircraft data from the MOZAIC/IAGOS project for the EASM of 2008-2013 are used to validate the IASI data and to assess the effect of the monsoon on the vertical distribution of the tropospheric $\mathrm{O}_{3}$ at different locations. Results show good agreement with a correlation coefficient of $0.73(12 \%)$ between the $0-6 \mathrm{~km}$ $\mathrm{O}_{3}$ column derived from IASI and aircraft data. IASI cap-
\end{abstract}

tures very well the inter-annual variation of tropospheric $\mathrm{O}_{3}$ observed by the aircraft data over the studied domain. Analysis of vertical profiles of the aircraft data shows a decrease in the tropospheric $\mathrm{O}_{3}$ that is more important in the free troposphere than in the boundary layer and at $10-20^{\circ} \mathrm{N}$ than elsewhere. Ground station data at different locations in India and China show a spatiotemporal dependence on meteorology during the monsoon, with a decrease up to $22 \mathrm{ppbv}$ in Hyderabad, and up to 5 ppbv in the North China Plain.

\section{Introduction}

Over South and East Asia, tropospheric ozone $\left(\mathrm{O}_{3}\right)$ concentrations have significantly increased over the past few decades as a result of rapid urbanization (Cooper et al., 2014) with important implications on regional and global air quality. South and East Asian countries are experiencing increasing emissions of different pollutants, many of which are precursors of $\mathrm{O}_{3}$ (Akimoto, 2003; Ohara et al., 2007; Richter et al., 2005). For example, China showed an increase of $\mathrm{NO}_{2}$ reaching $29 \%$ per year for the period 1996-2006 (van der 
A et al., 2008), and about $50 \%$ over the industrial areas of China over the period 1996-2004 (Richter et al., 2005), though recent $\mathrm{NO}_{2}$ observations from space are suggesting an $\mathrm{NO}_{2}$ decrease in 2013 and 2014 (Richter et al., 2015). An increase in background $\mathrm{O}_{3}$ concentrations is also detected in Southern China during the last decade (T. Wang et al., 2009). In Eastern China, a study by Xu et al. (2008), analyzing longterm trends at a background surface $\mathrm{O}_{3}$ station in Linan, suggests enhanced $\mathrm{O}_{3}$ variability linked to the increase in $\mathrm{NO}_{x}$ $\left(\mathrm{NO}_{x}=\mathrm{NO}_{2}+\mathrm{NO}\right)$ concentrations. Over most of India, increasing trends in tropospheric $\mathrm{O}_{3}$ are consistent with the observed trends in emissions from $\mathrm{NO}_{x}$ and carbon monoxide (CO) as well as coal and petroleum consumption (Lal et al., 2012).

The Asian monsoon circulation dominates the regional meteorology of southern and East Asia. In summer, the East Asian Summer Monsoon (EASM) is characterized by torrential rain, strong winds carrying clean air from the ocean over the heated tropical land and deep convection processes forming cirrus clouds and further rain (Lawrence and Lelieveld, 2010). Surface observations have shown that the EASM is responsible for a decrease in surface $\mathrm{O}_{3}$ at a rural site near Beijing (Wang et al., 2008) and a coastal site near Hong Kong (Lam et al., 2001; T. Wang et al., 2009). Yang et al. (2014) found that the largest impacts of EASM on the decrease in surface $\mathrm{O}_{3}$ are found over central and western China, while Beijing (North East China) and Nanjing (East China) experience a summertime $\mathrm{O}_{3}$ maxima during June and July respectively (Ding et al., 2008, 2013). Ozonesondes measurements have also detected the effect of the EASM on lower tropospheric $\mathrm{O}_{3}$ (Chan et al., 1998; Zhou et al., 2013). Satellite measurements over South and East Asia have been used to assess the daily variability of tropospheric $\mathrm{O}_{3}$, notably from the Infrared Atmospheric Sounding Interferometer (IASI) (Dufour et al., 2015). The effect of the EASM on the tropospheric $\mathrm{O}_{3}$ was previously detected with a decrease in the $\mathrm{O}_{3}$ partial column using data from IASI over several Indian and Chinese cities (Dufour et al., 2010; Safieddine et al., 2013). Using the Ozone Monitoring Instrument (OMI) and Microwave Limb Sounder (MLS) measurements, together with a regional chemistry and transport model, Zhao et al. (2010) showed that the air quality over southeastern China is affected by the EASM, leading to an influence extending to central East China from June to July. At $300 \mathrm{hPa}$, the Tropospheric Emission Spectrometer (TES) observations over India showed enhanced $\mathrm{O}_{3}$ abundances during June and July followed by a decrease in August (Worden et al., 2009).

The main objective of this study is to document the effect of the monsoon on the regional and vertical distribution of tropospheric $\mathrm{O}_{3}$ in East Asia during the summer using different observation data sets and relating them to one another. After this introduction, Sect. 2 will look at 6 years of tropospheric $0-6 \mathrm{~km} \mathrm{O}_{3}$ data and at a case study of the monsoon of 2011. We study the relationship between the tropospheric 0 $6 \mathrm{~km} \mathrm{O}_{3}$ and $\mathrm{CO}$ total columns from IASI and different me- teorological parameters from the ECMWF (European Centre for Medium-Range Weather Forecasts) Reanalysis (ERA) (winds, cloud cover and relative humidity) (Dee et al., 2011). Section 3 will look at a dense set of vertical $\mathrm{O}_{3}$ airborne profiles (363 in total) used to validate the IASI-O3 columns as well assess how well IASI captures the inter-annual variability of the EASM as observed by the aircraft data. Section 4 will look at a ground stations data set at five locations: Hyderabad, Udaipur, Jabalpur, Pearl River Delta (PRD) and North China Plain (NCP), during the EASM of 2011. Conclusions are given in Sect. 5.

\section{Tropospheric $\mathrm{O}_{3}$ from IASI during the EASM}

\subsection{The IASI instrument}

The IASI instruments launched onboard the MetOp platforms in October 2006 (IASI-A) and September 2012 (IASIB) are nadir looking Fourier transform spectrometers that probe the Earth's atmosphere in the thermal infrared spectral range between 645 and $2760 \mathrm{~cm}^{-1}$, with a spectral resolution of $0.5 \mathrm{~cm}^{-1}$ (apodized) and $0.25 \mathrm{~cm}^{-1}$ spectral sampling. In this study, and to have a consistent $\mathrm{O}_{3}$ product over the period 2008-2013, only IASI-A data have been used. The IASI footprint is a matrix of $2 \times 2$ pixels, each with $12 \mathrm{~km}$ diameter at nadir. IASI monitors the atmospheric composition at any location two times per day (the satellite's ground track is at about 09:30 local time in the morning and 21:30 in the evening). Each IASI measures many of the chemical components that play a key role in the climate system and in several aspects of atmospheric pollution. Global distributions of $\mathrm{O}_{3}$ vertical profiles are retrieved in near real time using a dedicated radiative transfer and retrieval software for the IASI $\mathrm{O}_{3}$ product, the Fast Optimal Retrievals on Layers for IASI (FORLI-O 3 ) (Hurtmans et al., 2012). Data are selected using a filter for scenes with no or low cloud coverage (below 13\%), and by rejecting all observations with root mean square (RMS) of the spectral fit residual larger than $3.5 \times 10^{-8} \mathrm{~W} \mathrm{~cm}^{-2} \mathrm{sr} \mathrm{cm}^{-1}$. Details about the chemical components that can be measured by IASI can be found in Clerbaux et al. (2009), Coheur et al. (2009) and Clarisse et al. (2011). IASI tropospheric $\mathrm{O}_{3}$ retrieved from FORLI has been extensively validated against ozonesondes during the period 2008-2014 and results show that IASI underestimates tropospheric $\mathrm{O}_{3}$ by 12 to $14 \%$ in the mid-latitudes and tropics (Boynard et al., 2016).

\subsection{Tropospheric $\mathrm{O}_{3}$ during the EASM for 2008-2013}

To look at the inter-seasonal and inter-annual variation of tropospheric $\mathrm{O}_{3}$ during the monsoon, we show in Fig. 1 the monthly distribution (May-September) of the IASI 0$6 \mathrm{~km} \mathrm{O}_{3}$ column over the period 2008-2013. Only IASI daytime observations are used, since better thermal contrast, and hence better sensitivity to the lower troposphere, is usually 


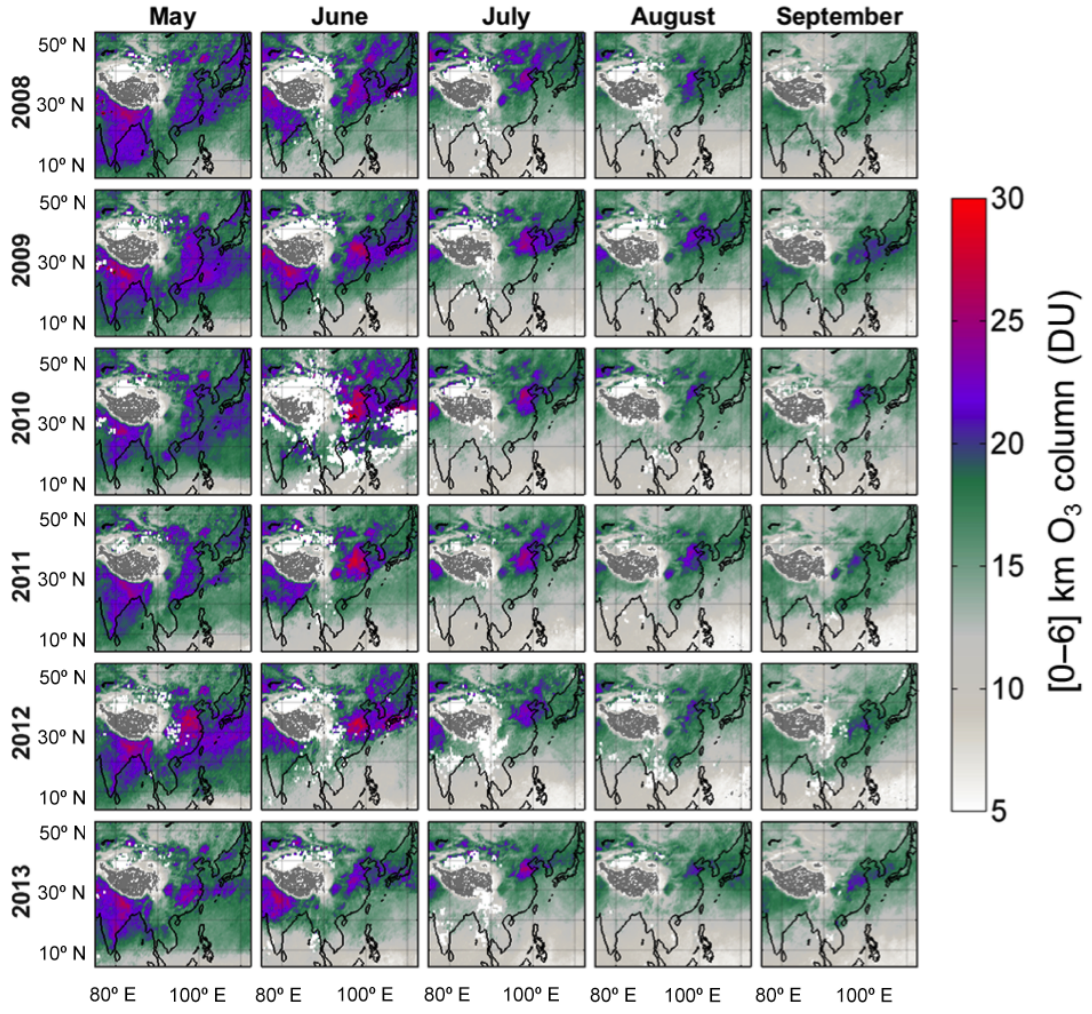

Figure 1. Monthly averaged daytime tropospheric $0-6 \mathrm{~km} \mathrm{O}_{3}$ column from IASI over the EASM region and period (May-September) for the years 2008-2013. The decrease due to the monsoon is more prominent to the south of the domain.

obtained during the day (Clerbaux et al., 2009). Earlier studies have shown that the information content in the satellite measurement varies, and is generally maximal in the midto upper troposphere, and lower at the surface (Barret et al., 2011; Dufour et al., 2012; Safieddine et al., 2014). The 0$6 \mathrm{~km} \mathrm{O} \mathrm{O}_{3}$ column is used to eliminate any possible stratospheric intrusions and previous studies have shown that with the $0-6 \mathrm{~km}$ column, at least one piece of information is available for the IASI retrieval (Barret et al., 2011; Dufour et al., 2012). Limitations in the sensitivity provide sources of error that can influence our conclusions about the observed $\mathrm{O}_{3}$ distribution, especially close to the surface. Another source of error emerge from the fact that the IASI observations used here are for scenes (pixels) with no or low cloud contamination, and therefore reflect mostly the state of the atmosphere before or after the rain/high cloud episodes that the EASM will generate.

The monthly average tropospheric $\mathrm{O}_{3}$ columns from IASI shown here have different observation counts at each grid point, which may correspond to the average of one to more than 200 observations. Despite these limitations, this is the best-known data set of remote infrared retrieved $\mathrm{O}_{3}$ columns covering the entire monsoon region, and we assume that the average effect of the monsoon on the tropospheric $\mathrm{O}_{3}$ column from one month to the other can be reflected in one or more observations. The seasonal variation of $\mathrm{O}_{3}$ as detected by IASI is highly dependent on photochemical activity and is generally higher in summer and lower in winter (Safieddine et al., 2013). However, within the EASM region, IASI shows in Fig. 1 that this typical seasonality is broken and on average, the $0-6 \mathrm{~km} \mathrm{O}_{3}$ columns are lower in June-JulyAugust (JJA) in comparison with May. The Asian monsoon onset date is around the mid-May and June (Parthasarathy et al., 1994; B. Wang et al., 2009; Yang and Lau, 1998). Figure 1 shows that the largest decrease is recorded in southern India, where clean air masses from the Pacific starting typically in May (generating the Indian Summer Monsoon, a subsystem of the EASM) will be responsible of a decrease reaching 15-20 Dobson unit (DU) in JJA. With the march of the monsoon northeastward, the decrease becomes most prominent in July and August at higher latitudes. To understand the year-to-year variability in tropospheric ozone, we looked at possible stratospheric intrusions into the $0-6 \mathrm{~km} \mathrm{O}_{3}$ column. Potential vorticity (PV) and the water vapor mixing ratio (Qvap) measurements were used as markers of transport from the upper troposphere-lower stratosphere (UTLS) to the troposphere, and extracted at different altitudes. We used data from the ERA-interim reanalysis (more info about this data set is provided in Sect. 2.3), and it was seen that downward transport from the UTLS can have an effect at altitude 
$>10 \mathrm{~km}$ and latitudes $>30^{\circ} \mathrm{N}$ (results not shown here). The analysis therefore suggests that the $0-6 \mathrm{~km} \mathrm{O}_{3}$ monthly averaged columns studied here are not affected by transport from the stratosphere. We also looked at the year-to-year variations associated with changes in regional emissions to study their effect on local production of ozone. We use emission estimates of $\mathrm{NO}_{x}$ and non-methane hydrocarbons, which are $\mathrm{O}_{3}$ precursors, from EDGAR-HTAP project (http://edgar.jrc. ec.europa.eu/htap_v2/index.php) available for only 2008 and 2010. An increase in both $\mathrm{NO}_{x}$ and non-methane hydrocarbons is observed between 2008 and 2010 over the studied domain and months, except for Japan (see Fig. S1 in the Supplement). Note that strict controls on vehicles and industries emissions were implemented for the summer Olympic and Paralympic Games in Beijing between July and September 2008 (United Nations Environment Programme, 2009). Traffic was reduced by $22 \%$ during the Olympics (Wang and Xie, 2009) and restrictions were applied on polluting industries in Beijing and surrounding provinces ( $\mathrm{Li}$ et al., 2009). While these standards did not include surface $\mathrm{O}_{3}$ limitations, $\mathrm{O}_{3}$ values were expected to be indirectly affected. When comparing 2008 to the rest of the years, $\mathrm{O}_{3}$ distributions do not show a significant decrease in Beijing and/or the surrounding regions (in fact August 2010 and 2012 have lower $\mathrm{O}_{3}$ values over Beijing than those recorded in 2008), a result also detected in previous studies looking at $\mathrm{O}_{3}$ surface measurements (Chou et al., 2011; Wang et al., 2010). Studies suggested $\mathrm{O}_{3}$ transport by winds from nearby polluted areas such as the North China Plain (Y. Wang et al., 2009; Wang et al., 2010), or $\mathrm{O}_{3}$ formation in the boundary layer since the photostationary state of the nitrogen cycle was perturbed (Wang and Xie, 2009). Over the rest of the domain, the increase in emissions of $\mathrm{O}_{3}$ precursors, at least between 2008 and 2010, suggests that tropospheric ozone values also increased between these 2 years during the different months, but the IASI-O ${ }_{3}$ columns do not show the same pattern. The analysis presented here suggests therefore that the meteorology associated with the EASM is the main driver of the $\mathrm{O}_{3}$ regional distribution and year-to-year variability. Over the different years, the seasonal variation is well reproduced but the decrease in the tropospheric $\mathrm{O}_{3}$ column will therefore change in magnitude depending on the monsoon strength. For example, in June 2010, around $30^{\circ} \mathrm{N}$ and $120-130^{\circ} \mathrm{E}$, the Western North Pacific region shows void area of IASI retrievals (with white pixels) due to large cloud cover. The Western North Pacific Monsoon Index (WNPI, Wang and Fan, 1999) is the highest in 2010 over this region in comparison with the rest of the years shown here. On the other hand, 2011 is rather a typical monsoon season year, and will be used as a case study hereafter.

\subsection{Case study of 2011}

In order to look at the $\mathrm{O}_{3}$ response to change in meteorology during the monsoon, we show in Fig. 2 the monsoon period
May-August of 2011 taken as an example year of a typical monsoon. Carbon monoxide (CO) total columns from IASI are also shown. CO is often used as an anthropogenic pollution and biomass-burning tracer (e.g. Edwards et al., 2004; McMillan et al., 2010). Note that the seasonal variation of $\mathrm{CO}$ is such that it is lower in summer, because of the destruction of $\mathrm{CO}$ by the $\mathrm{OH}$ radical in the presence of sunlight. We consider different meteorological parameters in order to highlight the relationship between change in meteorology and the $0-6 \mathrm{~km} \mathrm{O}_{3}$ column. These are the following: (i) the total cloud cover that gives an insight on the photochemical activity in the troposphere, (ii) relative humidity, since increasing water vapor increases $\mathrm{O}_{3}$ loss as the production rate of the reactions $\mathrm{H}_{2} \mathrm{O}+\mathrm{O}\left({ }^{1} \mathrm{D}\right) \rightarrow 2 \mathrm{OH}$ increases (where $\mathrm{O}\left({ }^{1} \mathrm{D}\right)$ is the product of the photo-dissociation of $\mathrm{O}_{3}$ in the presence of ultraviolet light), and (iii) horizontal and vertical wind fields. Horizontal wind speed and direction are used to assess monsoon strength and possible transport. Vertical velocity is used to investigate possible ascending motion of air masses from the boundary layer towards the free troposphere. All of the meteorological parameters are extracted from the ECMWF re-analysis (Dee et al., 2011). The data assimilation produces four analyses per day at 00:00, 06:00, 12:00 and 18:00 UTC at 37 pressure levels from 1000 to $1 \mathrm{hPa}$. Monthly means of total cloud cover, relative humidity at $850 \mathrm{hPa}$ and $u, v$ and $w$ horizontal and vertical wind directions at $850 \mathrm{hPa}$ are extracted over a grid size of $0.75^{\circ} \times 0.75^{\circ}$.

During the EASM, the southwesterly monsoon flow brings warm, wet and clean air masses from the Indian Ocean to South, Southeast and East Asia. The winds at $850 \mathrm{hPa}$ in Fig. 2 show a typical monsoon flow where in May and June, it mostly impacts South and Southeast Asia while the coastal region of East Asia is impacted by south-easterlies from the Pacific. In June, in particular, the monsoon becomes stronger as the wind force and the cloud cover (and therefore lower photochemical activity) increase over the regions $<20^{\circ} \mathrm{N}$. A decrease in tropospheric $\mathrm{O}_{3}$ and total $\mathrm{CO}$ columns is recorded over India, and over all the countries around the Bay of Bengal and South East China. In Southern India, negative (ascending winds, over the Arabian Sea) and positive (descending winds, over land) vertical velocities are present from the surface up to $700 \mathrm{hPa}$ (we show here an example at $850 \mathrm{hPa}$ ) suggesting exchanges of air masses vertically. Since CO's chemistry does not depend on cloud cover, the decrease in $\mathrm{CO}$ between May and June suggests that transport might be the main driver of decrease in pollutants. During July and August, the monsoon reaches its maximal strength. Due to high cloud cover and strong horizontal winds, the tropospheric $\mathrm{O}_{3}$ columns show a large decrease. For latitudes $<30^{\circ} \mathrm{N}$, the drop in $\mathrm{O}_{3}$ is more notable, particularly over the Indo-Gangetic Plain where the decline in $\mathrm{O}_{3}$ is driven by decreasing photochemistry since $\mathrm{CO}$ values over this region do not follow the same trend.

Looking at specific regions, tropospheric $0-6 \mathrm{~km} \mathrm{O}_{3}$ columns in Korea show a decrease in particular in July for 

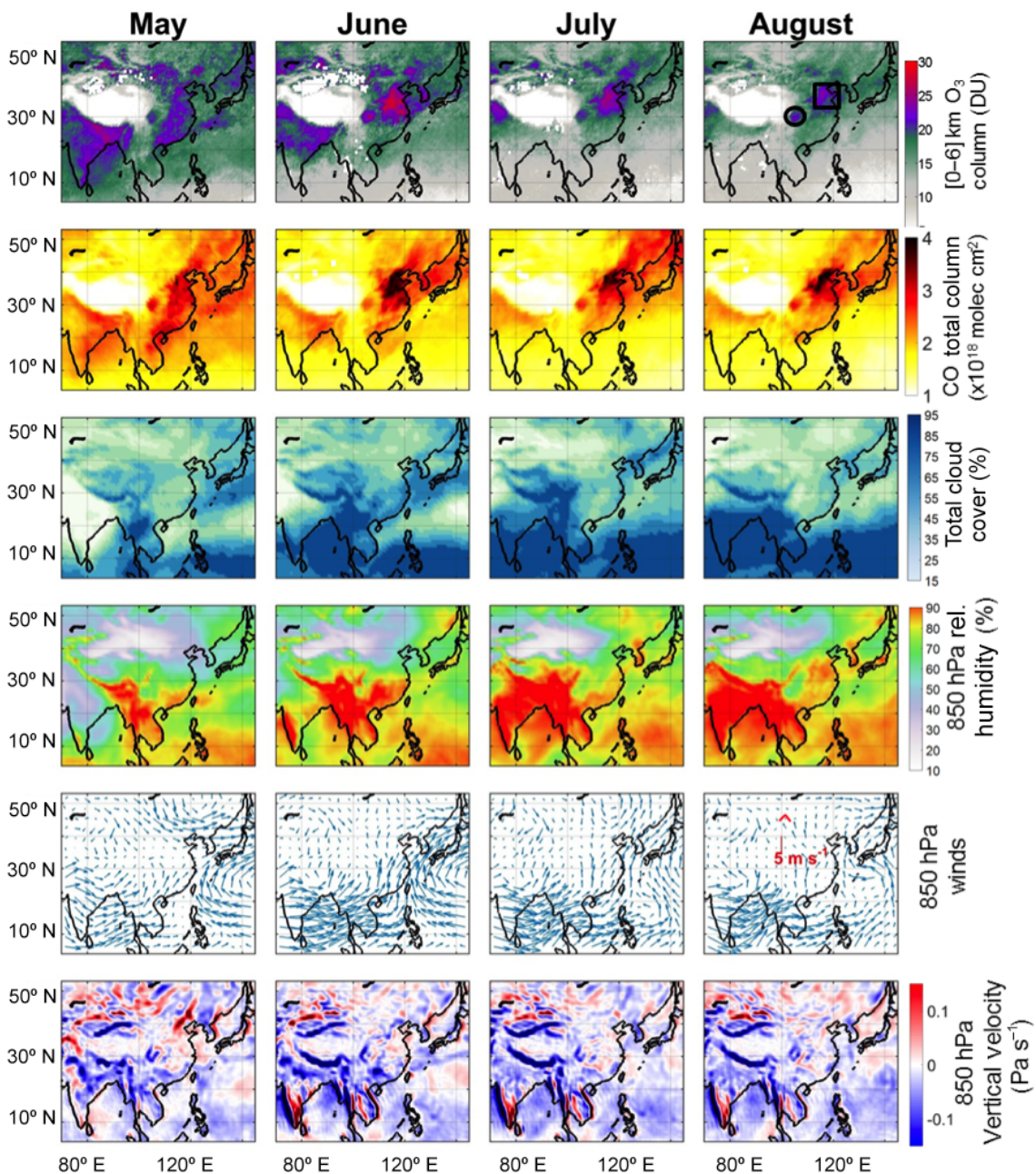

Figure 2. Monthly averaged tropospheric $0-6 \mathrm{~km} \mathrm{O}_{3}$ column from IASI, CO total columns from IASI, along with ECMWF total cloud cover, relative humidity, horizontal and vertical winds at $850 \mathrm{hPa}$ for each of the months of May to August 2011. The black square and circle (upper right plot) are the regions the least affected by the EASM and discussed more in the text.

$\mathrm{O}_{3}$ (and not for $\mathrm{CO}$ ), which coincides with the high cloud cover and relative humidity. On the other hand, and over North West of India and part of Pakistan, the low cloud cover and weak winds lead to the buildup of the high summer $\mathrm{O}_{3}$ over this region. Enhanced IASI CO columns over this same region suggest build-up of pollutants, and with little to no transport, the persistence of the $0-6 \mathrm{~km} \mathrm{O}_{3}$ values. Looking at the winds plots over the different months, one can notice how the monsoon is stronger at the lower latitudes of the domain. Therefore the areas of Beijing, Tianjin and the North China Plain (black square in Fig. 2) are in general less affected by the monsoon and they show much weaker $\mathrm{O}_{3}$ decrease. High CO total columns, used as pollution tracer, indicate the anthropogenic origin of the observed ozone enhancements. In fact, the persistence of $\mathrm{O}_{3}$ during the monsoon season in Beijing was previously documented using aircraft data from the MOZAIC program which suggested a summertime $\mathrm{O}_{3}$ maximum attributed to strong photochemical production
(Ding et al., 2008). The other interesting region in China that shows little or no change is the area between the Chongqing and Sichuan provinces (and designated with a black circle in Fig. 2). This region does not exhibit any monsoon characteristics with low cloud cover and weak winds. This region is also between two mountains, making the persistence of $\mathrm{O}_{3}$ and $\mathrm{CO}$ during summer favorable. The vertical velocity plots show that the monsoonal convection responsible of uplift of pollutants from the boundary layer to the free and upper troposphere, is more prominent for latitudes $<30^{\circ} \mathrm{N}$, except for Southern India, in accordance with previous studies (e.g. Randel et al., 2010; Fadnavis et al., 2013, 2015).

\section{Tropospheric $\mathrm{O}_{3}$ from MOZAIC/IAGOS}

The Measurements of OZone and water vapor by in-service AIrbus airCraft (MOZAIC) program currently known as the 
European In-service Aircraft for a Global Observing System (IAGOS) program (Nedelec et al., 2015), has provided in situ observations of ozone, water vapor, carbon monoxide and other trace gases made from multiple commercial aircraft since 1994 (Marenco et al., 1998; Thouret et al., 1998; http://www.iagos.org). In this study, we start by performing a validation analysis of the IASI data with 363 profiles from aircraft take-off and landing; we then check how well IASI captures the inter-annual variation of $\mathrm{O}_{3}$ seen by the aircraft data and finally we look at the monthly averaged vertical profiles of tropospheric $\mathrm{O}_{3}$ over our study domain.

\subsection{Validation of IASI data}

The IASI-retrieved tropospheric $\mathrm{O}_{3}$ product is not a real concentration profile, but an estimation of the true profile considering the ability of the instrument to discriminate different atmospheric layers. Therefore one cannot directly compare satellite-retrieved profiles with high-resolution in situ observations such as the aircraft data. Instead, each high-resolution $\mathrm{O}_{3}$ profile measured by the aircraft needs to be convolved by the low-resolution IASI averaging kernel matrix with the a priori profile, following Rodgers (2000) formulation:

$x_{\text {smoothed }}=x_{\mathrm{a}, \mathrm{IASI}}+A_{\mathrm{IASI}}\left(x_{\text {aircraft }}-x_{\mathrm{a}, \mathrm{IASI}}\right)$,

where $x_{\text {smoothed }}$ is the smoothed profile that uses lowresolution measurement characteristics. $\mathrm{A}_{\mathrm{IASI}}$ is the lowresolution averaging kernel matrix. $x_{\text {aircraft }}$ is the highresolution profile given by the aircraft, and $x_{\mathrm{a}, \text { IASI }}$ is the low-resolution IASI a priori profile constructed from the McPeters/Labow/Logan climatology of $\mathrm{O}_{3}$ vertical distribution, which combines long-term satellite limb measurements and measurements from ozonesondes (see McPeters et al., 2007; Hurtmans et al., 2012). Before the smoothing, the validation profile has to cover the whole retrieval altitude range, which is from the ground up to $41 \mathrm{~km}$. The aircraft data profiles were therefore completed by the same a priori used for IASI so that the matrix calculation of Eq. (1) is valid. We have also used an IASI spatial coincidence criterion of $\pm 200 \mathrm{~km}$ around the position of the aircraft ascent or descent. In this section, both IASI day and nighttime observations are used for the validation of the aircraft data, and the temporal coincidence is $\pm 10 \mathrm{~h}$.

Figure 4 shows the correlation of $0-6 \mathrm{~km} \mathrm{O}_{3}$ column retrieved from spatio-temporal coincidence of 363 IASI and MOZAIC/IAGOS smoothed profiles during May-August of 2008-2013 (except for 2010 where no aircraft profiles were available), and over the airports located in the study domain (see Fig. 3 for the location). Over the 5 years, a good agreement between the two data sets is found with correlation of 0.73 and absolute relative bias of $12 \pm 9 \%$. Analysis of each year data leads to correlations ranging between 0.7 and 0.8 and bias ranging between 11 and $19 \%$. Our results suggest a good ability of IASI to reproduce $\mathrm{O}_{3}$ variability in the troposphere over this region. Discrepancies arise from the spa-

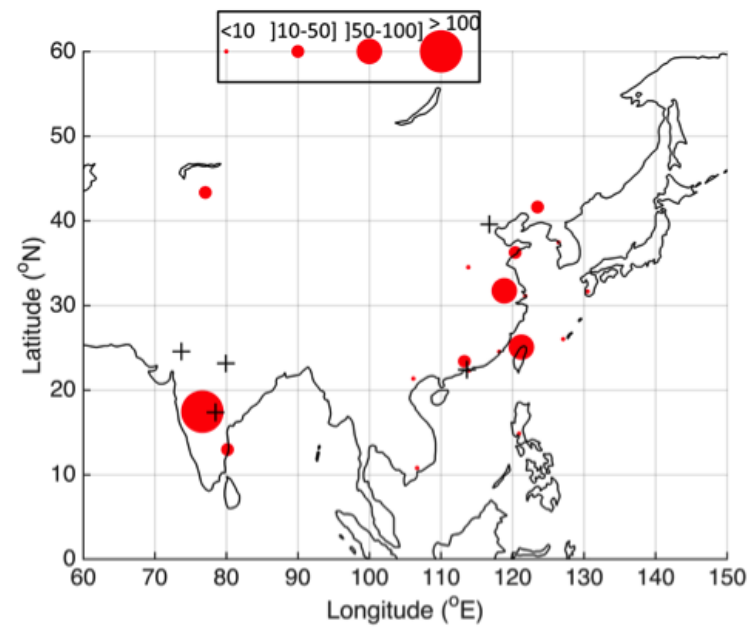

Figure 3. In red and scaled to number of observations: location of the MOZAIC/IAGOS flight data at the different airports in our study domain and period. The "+" sign locations corresponds to the ground stations used in Sect. 4 for the year 2011.

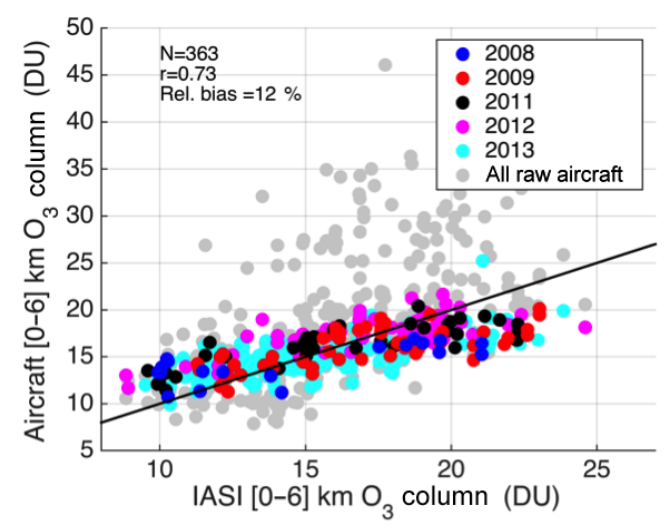

Figure 4. The $0-6 \mathrm{~km} \mathrm{O}_{3}$ columns retrieved from IASI correlation with 363 coincident MOZAIC/IAGOS profiles convolved with IASI averaging kernels for the period May-August of 2008-2013. No aircraft data are available for 2010. Grey dots correspond to raw aircraft $\mathrm{O}_{3}$ columns before smoothing.

tial resolution of the IASI footprint resulting in an observation averaged over tens of kilometers around the airport and therefore may include other surface $\mathrm{O}_{3}$ contributions. Moreover, the aircraft observation takes place at different times during the day whereas IASI observation is at around 09:30 and 21:30 local time. With its limited sampling time during the day and its lower sensitivity towards the surface, IASI observation is not able to capture the diurnal variation of $\mathrm{O}_{3}$ like an aircraft profile. Our results show a declined correlation between IASI and aircraft products as compared to Barret et al. (2011) where they reported a correlation coefficient of $0.87(12 \pm 6 \%)$. This could be due to the different retrieval algorithm used: SOFRID (Barret et al., 2011) vs. FORLI (Hurtmans et al., 2012). A discussion of the dif- 

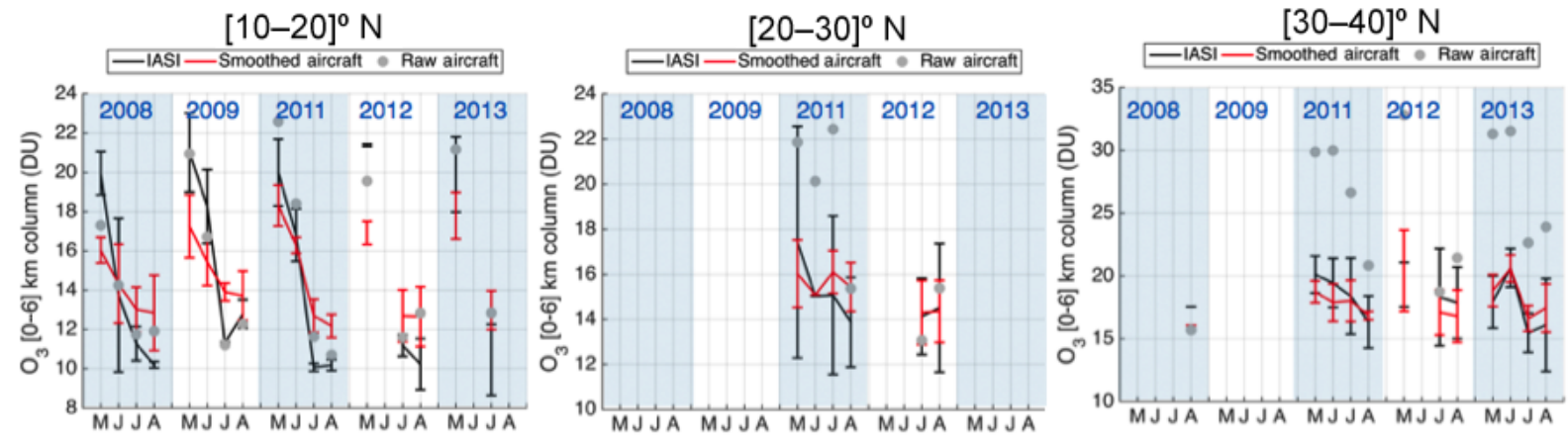

Figure 5. Time series of $0-6 \mathrm{~km}$ available $\mathrm{O}_{3}$ columns from co-located IASI (black) and aircraft (smoothed in red and raw in grey) data at the airports (Fig. 3) averaged between 10-20, 20-30 and 30-40 $\mathrm{N}$ from May till August of 2008 to 2013. No aircraft data were recorded in 2010 .

ferences between the two algorithms can be found in Dufour et al. (2012). Another source of difference may arise from the different season and time period studied (Barret et al., 2011 uses a 6-month profiles over the period JulyDecember 2008). Over the monsoon period, and in particular in May and June, the diurnal variability of tropospheric ozone is much more pronounced and highly dependent on the local meteorology. Therefore, discrepancies between IASI and the aircraft profile will carry larger discrepancies given the $\pm 10 \mathrm{~h}$ coincidence criteria we used. Moreover, our study takes only the column from 0 to $6 \mathrm{~km} \mathrm{O}_{3}$ column from IASI whereas the lower tropospheric column used by Barret et al., 2011 is based on the column from the surface up to $250 \mathrm{hPa}$ $(\sim 10 \mathrm{~km})$ and IASI is known to have a better sensitivity in the upper middle troposphere (Boynard et al., 2009; Safieddine et al., 2013).

Figure 5 shows the time series of the columns plotted in Fig. 4 averaged over three latitude bands (the vertical bars are the standard deviation around the mean). The IASI-O ${ }_{3}$ product captures very well the inter-annual variability of the EASM as observed by the aircraft data over the different latitude bands. The decrease in the $\mathrm{O}_{3}$ columns is most important at $10-20^{\circ} \mathrm{N}$, and over the different years, a result that can also be seen in Fig. 1. Fewer data are available at $20-30^{\circ} \mathrm{N}$ (no co-located observations are recorded for 2008, 2009 and 2013). For 2011 for example, a decrease - though smaller in magnitude than the one in the $10-20^{\circ} \mathrm{N}-$ is recorded both by IASI and the aircraft observations between May and June. Between July and August, a decrease is recorded in 2011, and an increase is recorded in 2012, and both events are well captured by IASI. At $30-40^{\circ} \mathrm{N}$, the effect of the EASM on the tropospheric $\mathrm{O}_{3}$ column, as Figs. 1 and 2 showed, is weak or not clear. IASI captures very well the variability during both 2011 (the consistent slight decrease between May to August 2011), and 2013 (various increasing and/or decreasing behavior).

\subsection{Monsoon effect on the vertical profiles}

We show in Fig. 6 the monthly averaged (with the horizontal bars as standard deviation) raw MOZAIC profiles during the EASM of 2011 taken as an example year.

At $10-20^{\circ} \mathrm{N}$, and from May to June, a clear decrease of around $20 \mathrm{ppbv}$ in $\mathrm{O}_{3}$ volume mixing ratios (VMR) is recorded at 1 and $2 \mathrm{~km}$. At higher altitudes up to around $7 \mathrm{~km}$, an important decrease is also detected from May to June and then from June to both July and August. With a small standard deviation around the $\mathrm{O}_{3}$ profiles, the observations at $10-20^{\circ} \mathrm{N}$, suggest consistent averaged monthly behavior and show a decrease in the $\mathrm{O}_{3}$ profile at different altitudes from 0 to $7 \mathrm{~km}$, which was also seen over the whole $0-6 \mathrm{~km} \mathrm{O}_{3}$ column from IASI in Figs. 1 and 2. At $20-30^{\circ} \mathrm{N}$, the $\mathrm{O}_{3}$ VMR in the lower troposphere ( 1 to $5 \mathrm{~km}$, no monsoon signature at the surface) decreases from May to June of 10-20 ppbv but then increases back in July and/or August. At 5-8 km, the different months averaged $\mathrm{O}_{3}$ VMR becomes comparable. Looking at this latitude band in Fig. 2, we can see how the decrease in the lower tropospheric $\mathrm{O}_{3}$ in June can be explained by the increase in the cloud cover and in particular an increase in the wind speed at $850 \mathrm{hPa}$ coming from the west Pacific. The profiles located at $30-40^{\circ} \mathrm{N}$, except at the surface, show a decrease in the $\mathrm{O}_{3}$ VMR is detected from June to July and August (till $6 \mathrm{~km}$ ). All three averaged profiles show no monsoon signature at the surface, probably due to enhanced $\mathrm{O}_{3}$ precursor emissions near the ascent and descent of the aircraft.

\section{Ground-based measurements}

The MOZAIC profiles illustrated in Fig. 6 have shown that the effect of the EASM on surface and/or boundary layer $\mathrm{O}_{3}$ largely depends on the location. In this section, we investigate ground station data during the monsoon of 2011 over five different locations (see Fig. 3, "+" sign). We distinguish between the Indian and Chinese stations by the sampling 


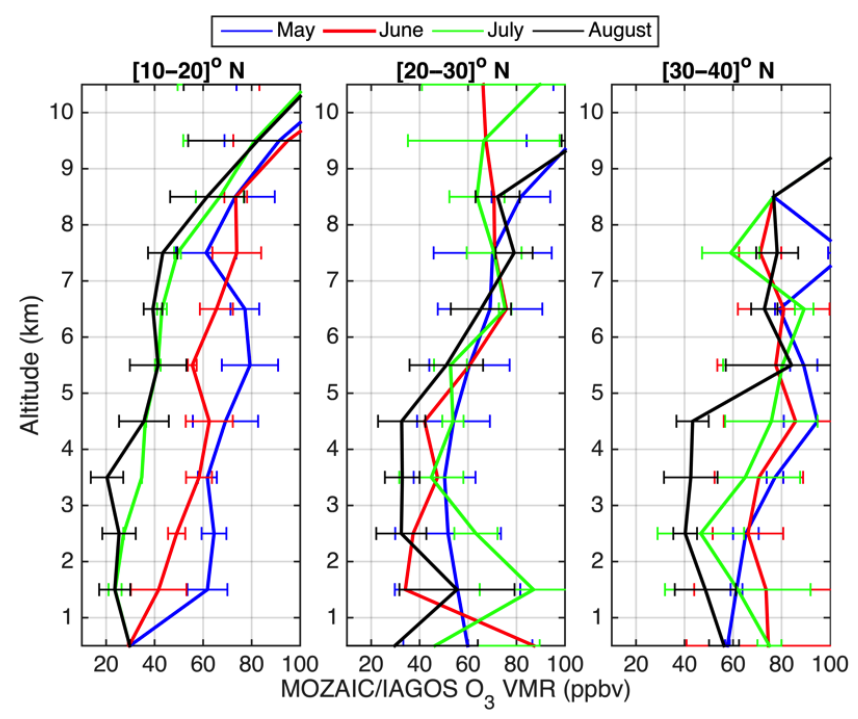

Figure 6. Monthly averaged vertical profiles of tropospheric $\mathrm{O}_{3}$ from MOZAIC during the period May-August 2011 at 10-20, 2030 and $30-40^{\circ} \mathrm{N}$. Error bars correspond to the standard deviation.

method. The three Indian stations shown here are provided with monthly means only. The two Chinese sites are a collection of stations and have hourly values: the data from the Pearl River Delta are the daily average of 12 stations, and the data from the North China Plain site are daily average over 7 stations. Details on the location, type and sampling method of the Indian and Chinese stations as well as discussion of each of the Chinese station data are provided in the Supplement. Figure 7 shows the surface $\mathrm{O}_{3}$ VMR for the Indian ground stations in panel (a) and for the Chinese ground stations in panel (b).

Hyderabad shows continuous decreasing $\mathrm{O}_{3}$ values from May to August, of total magnitude of $22 \mathrm{ppbv}$ in accordance with Fig. 6 at the same latitude band. Jabalpur is located in a region where the monsoon effect is strong as seen in Figs. 1 and 2 , and the $\mathrm{O}_{3}$ at the surface behaves similarly, with a decrease of 20 ppbv. Udaipur lies in a region where the monsoon is milder, leading to a small decrease in the summertime $\mathrm{O}_{3}$ values that decrease by $5 \mathrm{ppbv}$ between May and July and then increase back in August to $32 \mathrm{ppbv}$. Figure 7b station data are the $24 \mathrm{~h}$ running average (and the associated standard deviation in shaded blue) of 12 stations in the PRD region and 7 stations in the NCP region. Since we are interested in the regional EASM effect on $\mathrm{O}_{3}$, we show the average of the stations here (the stations are between 25 to $300 \mathrm{~km}$ away). For details and more timely resolved observations for each of the stations, please check the Supplement. The ground observations of the PRD stations, represented also by the $20-30^{\circ} \mathrm{N}$ MOZAIC profiles in Fig. 6, detect a decrease of $>35 \mathrm{ppbv}$ from June to July coinciding with when the northwesterly winds from the Pacific become stronger (see Fig. 2). The $\mathrm{O}_{3}$ VMR increase slightly afterwards dur-
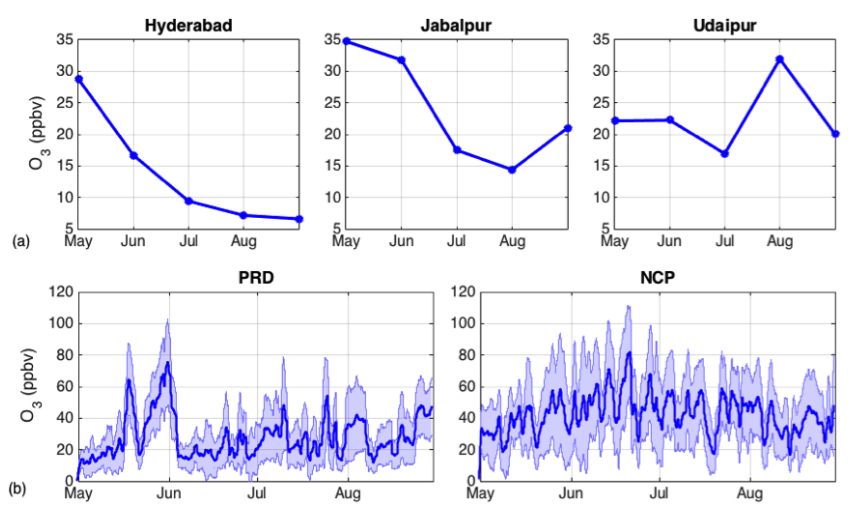

Figure 7. Ground station data during the EASM of 2011 over India: Hyderabad, Jabalpur and Udaipur in panel (a); and over China, Pearl River Delta (PRD), and North China Plain (NCP) in panel (b). The shaded region in panel (b) corresponds to the standard deviation of the 24-hour running average of the different stations in the PRD and NCP sites respectively. The location of the stations is plotted in Fig. 3, and more information is provided in the Supplement.

ing July and August due to the decrease in monsoon strength over this region (also seen in Fig. 2). Figure $7 \mathrm{~b}$ for the NCP stations shows a weak monthly decrease in $\mathrm{O}_{3}$ concentrations from June to July and August of 5-10 ppbv. The IASI and meteorological data presented in Fig. 2 also suggest the same decreasing pattern in $\mathrm{O}_{3}$ concentrations driven by the slight increase in cloud cover.

\section{Conclusions}

The East Asian Summer Monsoon plays an important role in changing the pollutants concentration as well as the weather and climate system over the monsoon regions leading to effects on the global air quality and climate system (Rodwell and Hoskins, 2001). The study of the dynamics and variability of the East Asian monsoon provides useful information to analyze the distribution and losses of pollutants such as tropospheric $\mathrm{O}_{3}$. The latter is shown to have a particular seasonal variation over south and East Asia due to the monsoon. This study shows that the monsoon variability is recorded and well captured over the different years by the infrared remote sensor IASI during 2008-2013. The IASI $0-6 \mathrm{~km} \mathrm{O}_{3}$ columns decrease starting in the months of May and June of each year, and reach a minimum in July-August. This decrease is most prominent in south Asia where the monsoon is stronger. In order to assess the monsoon meteorological signature on tropospheric $\mathrm{O}_{3}$, we compare tropospheric $\mathrm{O}_{3}$ to cloud cover, relative humidity and wind fields from the ERA-interim archive during the monsoon of 2011 taken as an example year. We add CO total columns from IASI to check if the regions showing persistence of ozone are stimulated by the presence of anthropogenic precursors. Over most of the domain, clear inverse relationship is seen between the 
IASI 0-6 km tropospheric $\mathrm{O}_{3}$ on one hand and cloud cover and winds on the other hand. This is explained by the fact that the high cloud cover that the monsoon generates, accompanied with high relative humidity in the troposphere lead to a lower production rate since the photochemical activity will be much lower and relative humidity is a sink of $\mathrm{O}_{3}$ in particular in the background troposphere. On the other hand, the winds are also strong during the monsoon and $\mathrm{O}_{3}$ during this period can be transported either vertically, or horizontally to or from the Pacific and to the globe. Validation of the IASI-O ${ }_{3}$ columns with aircraft data shows a good correlation $(r=0.73,12 \%)$ between the $0-6 \mathrm{~km}$ columns from IASI to that derived from 363 aircraft profiles. IASI is shown to reproduce very well the year-to-year variability in $\mathrm{O}_{3}$ seen by the aircraft data. A monsoon signature is detected on the $\mathrm{O}_{3}$ profiles over the different latitude bands of our study domain that is in agreement with the IASI $0-6 \mathrm{~km} \mathrm{O}_{3}$ column spatial distribution. Ground station measurements of $\mathrm{O}_{3}$ also show spatial dependence and are anti-correlated to the EASM strength. The stations in Central and North India as well as in Pearl River Delta show a signature of the monsoon on ground $\mathrm{O}_{3}$ that can be explained by the change in meteorology over these regions. In northwest India, and the North China plain, winds are weaker, and the cloud cover is smaller and thus the ground $\mathrm{O}_{3}$ shows a smaller decrease during the EASM.

More generally, this study shows that in case of no or scarce ground and aircraft measurements, satellite observations, such as the one provided in this work using IASI, provide valuable information that could help investigate the regional and global monsoon impact on the distribution of pollutants in the troposphere and in particular tropospheric $\mathrm{O}_{3}$. With IASI-C to be launched in 2018 onboard MetOp-C and a new series of three IASI-NG instruments on MetOp Second Generation Satellites around 2022 (Crevoisier et al., 2014), long-term IASI $\mathrm{O}_{3}$ time series obtained at high spatial resolution will be available to characterize and detect the onset and the progression of the monsoon.

\section{Data availability}

The ETHER database (http://www.pole-ether.fr; Ether, 2016) provides the IASI L1C data and L2 temperature data. MOZAIC/IAGOS data is available at http://www.iagos.org (IAGOS, 2016). Meteorological parameters used in this study are extracted from the ECMWF Reanalysis archive (ERA-Interim, 2016) and are available at http://apps.ecmwf. int/archive-catalogue/. Station data used are available by contacting the first author (sarahsaf@ mit.edu).

The Supplement related to this article is available online at doi:10.5194/acp-16-10489-2016-supplement.
Acknowledgements. IASI is a joint mission of EUMETSAT and the Centre National d'Etudes Spatiales (CNES, France). The IASI L1 data are distributed in near real time by EUMETSAT through the EumetCast system distribution. MOZAIC is presently funded by INSU-CNRS (France), Météo-France, Université Paul Sabatier (Toulouse, France) and Research Center Jülich (FZJ, Jülich, Germany). IAGOS has been and is additionally funded by the EU projects IAGOS-DS and IAGOS-ERI. The authors acknowledge the strong support of the European Commission, Airbus, and the Airlines (Lufthansa, Air-France, Austrian, Air Namibia, Cathay Pacific, Iberia and China Airlines so far) who carry the MOZAIC or IAGOS equipment and perform the maintenance since 1994. The authors are grateful to the ETHER database (http://www.pole-ether.fr) for providing the IASI L1C data and L2 temperature data. This study was carried out in the framework of the "East Asian Monsoon and air quality" project, which is a part of the DRAGON program (http://dragon3.esa.int), the EU-FP7 PANDA project (http://www.marcopolo-panda.eu/), the EUMETSAT O3M-SAF project, and the ESA O $\mathrm{O}_{3}$ Climate Change Initiative $\left(\mathrm{O}_{3}-\mathrm{CCI}\right)$. The French scientists are grateful to CNES and Centre National de la Recherche Scientifique (CNRS) for financial support. The research in Belgium is funded by the Belgian State Federal Office for Scientific, Technical and Cultural Affairs and the European Space Agency (ESA Prodex arrangement). P. F. Coheur is Senior Research Associate with F.R.S-FNRS.

Edited by: P. Monks

Reviewed by: four anonymous referees

\section{References}

Akimoto, H.: Global air quality and pollution, Science, 302, 17171719, 2003.

Barret, B., Le Flochmoen, E., Sauvage, B., Pavelin, E., Matricardi, M., and Cammas, J. P.: The detection of post-monsoon tropospheric ozone variability over south Asia using IASI data, Atmos. Chem. Phys., 11, 9533-9548, doi:10.5194/acp-11-95332011, 2011.

Boynard, A., Clerbaux, C., Coheur, P.-F., Hurtmans, D., Turquety, S., George, M., Hadji-Lazaro, J., Keim, C., and MeyerArnek, J.: Measurements of total and tropospheric ozone from IASI: comparison with correlative satellite, ground-based and ozonesonde observations, Atmos. Chem. Phys., 9, 6255-6271, doi:10.5194/acp-9-6255-2009, 2009.

Boynard, A., Hurtmans, D., Koukouli, M. E., Goutail, F., Bureau, J., Safieddine, S., Lerot, C., Hadji-Lazaro, J., Pommereau, J.-P., Pazmino, A., Zyrichidou, I., Balis, D., Barbe, A., Mikhailenko, S. N., Loyola, D., Valks, P., Van Roozendael, M., Coheur, P.-F., and Clerbaux, C.: Seven years of IASI ozone retrievals from FORLI: validation with independent total column and vertical profile measurements, Atmos. Meas. Tech. Discuss., doi:10.5194/amt2016-11, in review, 2016.

Chan, L. Y., Liu, H. Y., Lam, K. S., Wang, T., Oltmans, S. J., and Harris, J. M.: Analysis of the seasonal behavior of tropospheric ozone at Hong Kong, Atmos. Environ., 32, 159-168, doi:10.1016/S1352-2310(97)00320-8, 1998.

Chou, C. C.-K., Tsai, C.-Y., Chang, C.-C., Lin, P.-H., Liu, S. C., and Zhu, T.: Photochemical production of ozone in Beijing during 
the 2008 Olympic Games, Atmos. Chem. Phys., 11, 9825-9837, doi:10.5194/acp-11-9825-2011, 2011.

Clarisse, L., R'Honi, Y., Coheur, P. F., Hurtmans, D., and Clerbaux, C.: Thermal infrared nadir observations of 24 atmospheric gases, Geophys. Res. Lett., 38, L10802, doi:10.1029/2011GL047271, 2011.

Clerbaux, C., Boynard, A., Clarisse, L., George, M., Hadji-Lazaro, J., Herbin, H., Hurtmans, D., Pommier, M., Razavi, A., Turquety, S., Wespes, C., and Coheur, P.-F.: Monitoring of atmospheric composition using the thermal infrared IASI/MetOp sounder, Atmos. Chem. Phys., 9, 6041-6054, doi:10.5194/acp-9-6041-2009, 2009.

Coheur, P.-F., Clarisse, L., Turquety, S., Hurtmans, D., and Clerbaux, C.: IASI measurements of reactive trace species in biomass burning plumes, Atmos. Chem. Phys., 9, 5655-5667, doi:10.5194/acp-9-5655-2009, 2009.

Cooper, O. R., Parrish, D. D., Ziemke, J., Balashov, N. V., Cupeiro, M., Galbally, I. E., Gilge, S., Horowitz, L., Jensen, N. R., Lamarque, J.-F., Naik, V., Oltmans, S. J., Schwab, J., Shindell, D. T., Thompson, A. M., Thouret, V., Wang, Y., and Zbinden, R. M.: Global distribution and trends of tropospheric ozone: An observation-based review, Elem. Sci. Anthr., 2, 000029 , doi:10.12952/journal.elementa.000029, 2014.

Crevoisier, C., Clerbaux, C., Guidard, V., Phulpin, T., Armante, R., Barret, B., Camy-Peyret, C., Chaboureau, J.-P., Coheur, P.F., Crépeau, L., Dufour, G., Labonnote, L., Lavanant, L., HadjiLazaro, J., Herbin, H., Jacquinet-Husson, N., Payan, S., Péquignot, E., Pierangelo, C., Sellitto, P., and Stubenrauch, C.: Towards IASI-New Generation (IASI-NG): impact of improved spectral resolution and radiometric noise on the retrieval of thermodynamic, chemistry and climate variables, Atmos. Meas. Tech., 7, 4367-4385, doi:10.5194/amt-7-4367-2014, 2014.

Dee, D. P., Uppala, S. M., Simmons, A. J., Berrisford, P., Poli, P., Kobayashi, S., Andrae, U., Balmaseda, M. A., Balsamo, G., Bauer, P., Bechtold, P., Beljaars, A. C. M., van de Berg, L., Bidlot, J., Bormann, N., Delsol, C., Dragani, R., Fuentes, M., Geer, A. J., Haimberger, L., Healy, S. B., Hersbach, H., Holm, E. V, Isaksen, L., Kallberg, P., Kohler, M., Matricardi, M., McNally, A. P., Monge-Sanz, B. M., Morcrette, J.-J., Park, B.-K., Peubey, C., de Rosnay, P., Tavolato, C., Thepaut, J.-N., and Vitart, F.: The ERA-Interim reanalysis: configuration and performance of the data assimilation system, Q. J. Roy. Meteor. Soc., 137, 553-597, doi:10.1002/qj.828, 2011.

Ding, A. J., Wang, T., Thouret, V., Cammas, J.-P., and Nédélec, P.: Tropospheric ozone climatology over Beijing: analysis of aircraft data from the MOZAIC program, Atmos. Chem. Phys., 8, 1-13, doi:10.5194/acp-8-1-2008, 2008.

Ding, A. J., Fu, C. B., Yang, X. Q., Sun, J. N., Zheng, L. F., Xie, Y. N., Herrmann, E., Nie, W., Petäjä, T., Kerminen, V.-M., and Kulmala, M.: Ozone and fine particle in the western Yangtze River Delta: an overview of $1 \mathrm{yr}$ data at the SORPES station, Atmos. Chem. Phys., 13, 5813-5830, doi:10.5194/acp-13-58132013, 2013.

Dufour, G., Eremenko, M., Orphal, J., and Flaud, J.-M.: IASI observations of seasonal and day-to-day variations of tropospheric ozone over three highly populated areas of China: Beijing, Shanghai, and Hong Kong, Atmos. Chem. Phys., 10, 37873801, doi:10.5194/acp-10-3787-2010, 2010.
Dufour, G., Eremenko, M., Griesfeller, A., Barret, B., LeFlochmoën, E., Clerbaux, C., Hadji-Lazaro, J., Coheur, P.-F., and Hurtmans, D.: Validation of three different scientific ozone products retrieved from IASI spectra using ozonesondes, Atmos. Meas. Tech., 5, 611-630, doi:10.5194/amt-5-611-2012, 2012.

Dufour, G., Eremenko, M., Cuesta, J., Doche, C., Foret, G., Beekmann, M., Cheiney, A., Wang, Y., Cai, Z., Liu, Y., Takigawa, M., Kanaya, Y., and Flaud, J.-M.: Springtime daily variations in lower-tropospheric ozone over east Asia: the role of cyclonic activity and pollution as observed from space with IASI, Atmos. Chem. Phys., 15, 10839-10856, doi:10.5194/acp-1510839-2015, 2015.

Edwards, D. P., Emmons, L. K., Hauglustaine, D. A., Chu, A., Gille, J. C., Kaufman, Y. J., P'etron, G., Yurganov, L. N., Giglio, L., Deeter, M. N., Yudin, V., Ziskin, D. C., Warner, J., Lamarque, J.F., Francis, G. L., Ho, S. P., Mao, D., Chan, J., and Drummond, J. R.: Observations of Carbon Monoxide and Aerosol From the Terra Satellite: Northern Hemisphere Variability, J. Geophys. Res.-Atmos., 109, D24202, doi:10.1029/2004JD004727, 2004.

ERA-interim: ECMWF ReAnalysis, The European Centre for Medium-Range Weather Forecasts (ECMWF), available at: http://apps.ecmwf.int/archive-catalogue/, last access: 16 August 2016.

Ether: IASI L1C data and L2 temperature data, Institut Pierre Simon Laplace (France), Centre National de la Recherche Scientifique (CNRS, France), Centre national d'études spatiales, available at: http://www.pole-ether.fr, last access: 16 August 2016.

Fadnavis, S., Semeniuk, K., Pozzoli, L., Schultz, M. G., Ghude, S. D., Das, S., and Kakatkar, R.: Transport of aerosols into the UTLS and their impact on the Asian monsoon region as seen in a global model simulation, Atmos. Chem. Phys., 13, 8771-8786, doi:10.5194/acp-13-8771-2013, 2013.

Fadnavis, S., Semeniuk, K., Schultz, M. G., Kiefer, M., Mahajan, A., Pozzoli, L., and Sonbawane, S.: Transport pathways of peroxyacetyl nitrate in the upper troposphere and lower stratosphere from different monsoon systems during the summer monsoon season, Atmos. Chem. Phys., 15, 11477-11499, doi:10.5194/acp-15-11477-2015, 2015.

Hurtmans, D., Coheur, P. F., Wespes, C., Clarisse, L., Scharf, O., Clerbaux, C., Hadji-Lazaro, J., George, M., and Turquety, S.: FORLI radiative transfer and retrieval code for IASI, J. Quant. Spectrosc. Ra., 113, 1391-1408, doi:10.1016/j.jqsrt.2012.02.036, 2012.

IAGOS: European In-service Aircraft for a Global Observing System program, Centre National de la Recherche Scientifique (CNRS, France), Forschungszentrum Jülich, the Sixth Research Framework Programme (FP6), available at: http://www.iagos. org, last access: 16 August 2016.

Lal, D. M., Sachin, D. G., Patil, S. D., Kulkarni, S. H., Jena, C., Tiwari, S., and Srivastava, M. K.: Tropospheric ozone and aerosol long-term trends over the Indo-Gangetic Plain (IGP), India, J. Atmos. Res., 116, 82-92, doi:10.1016/j.atmosres.2012.02.014, 2012.

Lam, K. S., Wang, T. J., Chan, L. Y., Wang, T., and Harris, J.: Flow patterns influencing the seasonal behavior of surface ozone and carbon monoxide at a coastal site near Hong Kong, Atmos. Environ., 35, 3121-3135, doi:10.1016/S1352-2310(00)00559-8, 2001. 
Lawrence, M. G. and Lelieveld, J.: Atmospheric pollutant outflow from southern Asia: a review, Atmos. Chem. Phys., 10, 1101711096, doi:10.5194/acp-10-11017-2010, 2010.

Li, Y., Wang, W., Kan, H., Xu, X., and Chen, B.: Air quality and outpatient visits for asthma in adults during the 2008 summer Olympic Games in Beijing, Sci. Total Environ., 408, 1226-1227, 2009.

Marenco, A., Thouret, V., Nédélec, P., Smit, H., Helten, M., Kley, D., Karcher, F., Simon, P., Law, K., Pyle, J., Poschmann, G., Von Wrede, R., Hume, C., and Cook, T.: Measurement of ozone and water vapor by Airbus in-service aircraft: The MOZAIC airborne program, an overview, J. Geophys. Res., 103, 25631, doi:10.1029/98JD00977, 1998.

McMillan, W. W., Pierce, R., Sparling, L. C., Osterman, G., McCann, K., Fischer, M. L., Rappenglueck, B., Newton, R., Turner, D. D., Kittaka, C., Evans, K., Biraud, S., Lefer, B., Andrews, A., and Oltmans, S.: An Observational and modeling strategy to investigate the impact of remote sources on local air quality: A Houston, Texas case study from TEXAQS II, J. Geophys. Res.Atmos., 115, D01301, doi:10.1029/2009JD011973, 2010.

McPeters, R. D., Labow, G. J., and Logan, J. A.: Ozone climatological profiles for satellite retrieval algorithms, J. Geophys. Res.Atmos., 112, D05308, doi:10.1029/2005JD006823, 2007.

Nedelec, P., Blot, R., Boulanger, D., Athier, G., Cousin, J.-M., Gautron, B., Petzold, A., Volz-Thomas, A., and Thouret, V.: Instrumentation on commercial aircraft for monitoring the atmospheric composition on a global scale: the IAGOS system, technical overview of ozone and carbon monoxide measurements, Tellus B, 67, 27791, doi:10.3402/tellusb.v67.27791, 2015.

Ohara, T., Akimoto, H., Kurokawa, J., Horii, N., Yamaji, K., Yan, $\mathrm{X}$., and Hayasaka, T.: An Asian emission inventory of anthropogenic emission sources for the period 1980-2020, Atmos. Chem. Phys., 7, 4419-4444, doi:10.5194/acp-7-4419-2007, 2007.

Parthasarathy, B., Munot, A. A., and Kothawale, D. R.: All-India monthly and seasonal rainfall series: 1871-1993, Theor. Appl. Climatol., 49, 217-224, doi:10.1007/BF00867461, 1994.

Randel, W. J., Park, M., Emmons, L., Kinnison, D., Bernath, P., Walker, K. A., Boone, C., and Pumphrey, H.: Asian monsoon transport of pollution to the stratosphere, Science, 328, 611-613, doi:10.1126/science.1182274, 2010.

Richter, A., Burrows, J. P., Nu, H., Granier, C., and Niemeier, U.: Increase in tropospheric nitrogen dioxide over China observed from space, Nature, 437, 129-132, doi:10.1038/nature04092, 2005.

Richter, A., Hilboll, A., and Burrows J. P.: Revisiting satellite derived tropospheric $\mathrm{NO}_{2}$ trends, Poster presentation submitted to the EGU meeting, Vienna, Austria, 12-17 April 2015, available at: http://presentations.copernicus.org/EGU2015-10674_ presentation.pdf (last access: 16 August 2016), 2015.

Rodgers, C.: Inverse Methods for Atmospheric Sounding: Theory and Practice, Series on Atmospheric, Oceanic and Planetary Physics, vol. 2, World Scientific, Hackensack, Singapore, 2000.

Rodwell, M. J. and Hoskins, B. J.: Subtropical anticyclones and summer monsoons, J. Climate, 14, 3192-3211, 2001.

Safieddine, S., Clerbaux, C., George, M., Hadji-Lazaro, J., Hurtmans, D., Coheur, P. F., Wespes, C., Loyola, D., Valks, P., and Hao, N.: Tropospheric ozone and nitrogen dioxide measurements in urban and rural regions as seen by IASI and GOME-2, J. Geo- phys. Res.-Atmos., 118, 10555-10566, doi:10.1002/jgrd.50669, 2013.

Safieddine, S., Boynard, A., Coheur, P.-F., Hurtmans, D., Pfister, G., Quennehen, B., Thomas, J. L., Raut, J.-C., Law, K. S., Klimont, Z., Hadji-Lazaro, J., George, M., and Clerbaux, C.: Summertime tropospheric ozone assessment over the Mediterranean region using the thermal infrared IASI/MetOp sounder and the WRF-Chem model, Atmos. Chem. Phys., 14, 1011910131, doi:10.5194/acp-14-10119-2014, 2014.

Thouret, V., Marenco, A., Sabatier, P., Logan, J. A., Ndec, P., Grouhel, C., and Sabatier, P.: Comparisons of ozone measurements from the MOZAIC airborne program and the ozone sounding network at eight locations, J. Geophys. Res., 103, 2569525720, doi:10.1029/98JD02243, 1998.

United Nations Environment Programme: Independent environmental assessment: Beijing 2008 Olympic Games, ISBN 97892-807-2888-0, Nairobi, Kenya, 2009.

Van der A, R. J., Eskes, H. J., Boersma, K. F., van Noije, T. P. C., Van Roozendael, M., De Smedt, I., Peters, D. H. M. U., and Meijer, E. W.: Trends, seasonal variability and dominant $\mathrm{NO}_{x}$ source derived from a ten year record of $\mathrm{NO}_{2}$ measured from space, J. Geophys. Res.-Atmos., 113, D04302, doi:10.1029/2007JD009021, 2008.

Wang, B. and Fan, Z.: Choice of South Asian summer monsoon indices, B. Am. Meteorol. Soc., 80, 629-638, 1999.

Wang, B., Ding, Q., and Joseph, P. V: Objective definition of the Indian summer monsoon onset, J. Climate, 22, 3303-3316, doi:10.1175/2008JCLI2675.1, 2009.

Wang, T. and Xie, S.: Assessment of traffic-related air pollution in the urban streets before and during the 2008 Beijing Olympic Games traffic control period, Atmos. Environ., 43, 5682-5690, doi:10.1016/j.atmosenv.2009.07.034, 2009.

Wang, T., Wei, X. L., Ding, A. J., Poon, C. N., Lam, K. S., Li, Y. S., Chan, L. Y., and Anson, M.: Increasing surface ozone concentrations in the background atmosphere of Southern China, 19942007, Atmos. Chem. Phys., 9, 6217-6227, doi:10.5194/acp-96217-2009, 2009.

Wang, T., Nie, W., Gao, J., Xue, L. K., Gao, X. M., Wang, X. F., Qiu, J., Poon, C. N., Meinardi, S., Blake, D., Wang, S. L., Ding, A. J., Chai, F. H., Zhang, Q. Z., and Wang, W. X.: Air quality during the 2008 Beijing Olympics: secondary pollutants and regional impact, Atmos. Chem. Phys., 10, 7603-7615, doi:10.5194/acp10-7603-2010, 2010.

Wang, Y., McElroy, M. B., Munger, J. W., Hao, J., Ma, H., Nielsen, C. P., and Chen, Y.: Variations of $\mathrm{O}_{3}$ and $\mathrm{CO}$ in summertime at a rural site near Beijing, Atmos. Chem. Phys., 8, 6355-6363, doi:10.5194/acp-8-6355-2008, 2008.

Wang, Y., Hao, J., McElroy, M. B., Munger, J. W., Ma, H., Chen, D., and Nielsen, C. P.: Ozone air quality during the 2008 Beijing Olympics: effectiveness of emission restrictions, Atmos. Chem. Phys., 9, 5237-5251, doi:10.5194/acp-9-5237-2009, 2009.

Worden, J., Jones, D. B. A., Liu, J., Parrington, M., Bowman, K., Stajner, I., Beer, R., Jiang, J., Thouret, V., Kulawik, S., Li, J.-L. F., Verma, S., and Worden, H.: Observed vertical distribution of tropospheric ozone during the Asian summertime monsoon, J. Geophys. Res.-Atmos., 114, D13304, doi:10.1029/2008JD010560, 2009.

Xu, X., Lin, W., Wang, T., Yan, P., Tang, J., Meng, Z., and Wang, Y.: Long-term trend of surface ozone at a regional background 
station in eastern China 1991-2006: enhanced variability, Atmos. Chem. Phys., 8, 2595-2607, doi:10.5194/acp-8-2595-2008, 2008.

Yang, S. and Lau, K.-M.: Influences of Sea Surface Temperature and Ground Wetness on Asian Summer Monsoon, J. Climate, 11, 3230-3246, 1998.

Yang, Y., Liao, H., and Li, J.: Impacts of the East Asian summer monsoon on interannual variations of summertime surfacelayer ozone concentrations over China, Atmos. Chem. Phys., 14, 6867-6879, doi:10.5194/acp-14-6867-2014, 2014.
Zhao, C., Wang, Y., Yang, Q., Fu, R., Cunnold, D., and Choi, Y.: Impact of East Asian summer monsoon on the air quality over China: View from space, J. Geophys. Res.-Atmos., 115, D09301, doi:10.1029/2009JD012745, 2010.

Zhou, D., Ding, A., Mao, H., Fu, C., Wang, T., Chan, L. Y., Ding, K., Zhang, Y., Liu, J., Lu, A., and Hao, N.: Impacts of the East Asian monsoon on lower tropospheric ozone over coastal South China, Environ. Res. Lett., 8, 44011, doi:10.1088/17489326/8/4/044011, 2013. 